Zabytkoznawstwo i Konserwatorstwo XL, Toruń 2011

Barbara Behal

\title{
Ogrzewanie i przewietrzanie wnętrz w XIX wieku na podstawie polskiego czasopiśmiennictwa
}

$\mathrm{W}$

kontekście trudnej sytuacji politycznej na ziemiach polskich w XIX wieku na uwagę zasługuje prężnie rozwijające się polskojęzyczne czasopiśmiennictwo techniczne. Głównym celem pism technicznych było rozpowszechnianie wynalazków opisanych w zagranicznych publikacjach, które mogłyby posłużyć rozwojowi rodzimego przemysłu. Przeglądając polskie czasopisma z XIX wieku, widzimy, że nowinki techniczne, jakimi żył świat zachodniej Europy, docierały w krótkim czasie do polskiego czytelnika. Zagadnienia związane z efektywnym ogrzewaniem wnętrz zajmują szczególne miejsce w XIX-wiecznych opracowaniach, a bardzo popularne i szeroko opisywane w prasie zachodniej ogrzewanie ciepłym powietrzem, już w 1822 roku jest znane polskiemu czytelnikowi. Artykuł stanowi omówienie techniki ogrzewania wnętrz ciepłym powietrzem i ich przewietrzania opisywanej w polskich XIX-wiecznych pismach technicznych.

Już od czasów starożytnych szukano sposobu na ogrzanie wnętrz mieszkalnych. Hypocaustum jako systemu centralnego ogrzewania stosowano od IV wieku p.n.e. Jeszcze w XVII wieku nie znano sposobów na dostateczne ogrzanie wnętrz, mimo że komin, do odprowadzania dymu z paleniska, wynaleziono w XI wieku. Kominki w domach mieszczańskich służyły przede wszystkim do gotowania, drugą, i niespecjalnie efektywną, ich funkcją było ogrzewanie. Piece kaflowe znano w XVI-wiecznej Francji, ale zyskały one popularność dopiero w XVIII wieku. Około 1720 roku odkryto, jak konstruować kominki i kominy, aby spowodować ciąg powietrza. $\mathrm{W}$ ten sposób poczyniono pierwszy 
krok do wyeliminowania dymu w pomieszczeniu, ale również poprawiono spalanie, dając więcej ciepła do wnętrza ${ }^{1}$.

Cały XIX wiek to prace nad rozwiązaniami technicznymi, które zredukowałyby dym z kominków. Ze stu sześćdziesięciu dziewięciu wynalazków angielskich, opatentowanych między 1815 a 1832 rokiem, dotyczących pieców i kominków, prawie jedna trzecia miała na celu zmniejszenie lub likwidację dymienia. W XIX wieku każda książka na temat budowy domów zawierała przynajmniej jeden rozdział poświęcony wietrzeniu i skutkom „złego powietrza”. Pojawiły się opracowania, w których podawano wymagania, jakie muszą być spełnione, aby powietrze, którym oddycha człowiek w pomieszczeniu, było dobrej jakości. Porównując je do dzisiejszych norm, zdajemy sobie sprawę, że wielkości te były zbyt rygorystyczne, ale $\mathrm{z}$ drugiej strony badania XIX-wiecznych uczonych uzmysłowiły ludziom, że parametry dobrego klimatu można opracować, wyjaśnić i zmierzyć w sposób naukowy ${ }^{2}$. Niezwykle znamienne wydaje się zestawienie zapotrzebowania na świeże powietrze ludzi przebywających w różnych pomieszczeniach, sporządzone przez Zajączkowskiego w 1878 roku (il. 1). Dla porównania, dzisiaj w pomieszczeniach, w których przebywają ludzie, strumień objętości powietrza wentylacyjnego określany jest na podstawie normy $\mathrm{PN}-83 / \mathrm{B} 03430 / \mathrm{Az3}: 2000$ i powinien wynosić $20 \mathrm{~m}^{3} / \mathrm{h}$ na osobę, a w pomieszczeniach szczelnych, klimatyzowanych i wentylowanych $-30 \mathrm{~m}^{3} / \mathrm{h}$ dla każdej osoby ${ }^{3}$.

Ogrzewanie ciepłym powietrzem, tak popularne w XIX wieku, zapoczątkował wynalazek Jacoba Perkins’a, za który otrzymał od Towarzystwa Zachęcającego w Londynie srebrny medal. Wynalazek ten cieszył się dużym zainteresowaniem. Jako pierwszy zastosował go P. Hansard w swojej drukarni w Old Bailey ${ }^{4}$.

1 W. Rybczyński, Dom: krótka historia idei, Gdańsk-Warszawa 1996.

2 Ibidem.

3 L. Wolski, A. Kamiński, Wentylacja w obiektach sakralnych, „Ciepłownictwo, Ogrzewnictwo, Wentylacja” 2006, nr 7-8, s. 52-54.

4 P. Meisner, O ogrzewaniu mieszkań, fabryk, suszarń, i. t. p. za pomoca ocieplonego powietrza, iako środku najtańszym, naywygodnieiszym i od ognia naybezpiecznieyszym, „Izys Polska, czyli Dziennik umieiętności, wynalazków, kunsztów i rękodzieł" 1822, t. II, s. 187-197. 
Od 1820 roku w Królestwie Kongresowym zaczyna być wydawane pierwsze czasopismo techniczne - „Izys Polska. Dziennik umiejętności,

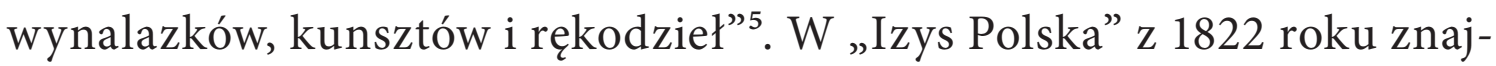
dujemy artykuł, który szeroko tłumaczy ogrzewanie pomieszczeń za pomocą ocieplonego powietrza według P. Meisnera - profesora chemii technicznej z Wiednia. Głównym zadaniem takiego systemu grzewczego miało być ogrzanie powietrza we wszystkich lub wybranych pomieszczeniach mieszkalnych budynku dzięki systemowi kanałów doprowadzających do nich ciepłe powietrze. Jednocześnie zimniejsze i „zużyte” powietrze miało być usuwane kanałami wentylacyjnymi, żeby „zrobić miejsce" dla napływającego, ciepłego powietrza. Drugim zadaniem oprócz ogrzania wnętrza było jego przewietrzanie, czyli wprowadzanie świeżego powietrza, które w zimie mogło być dodatkowo ogrzane. Główne założenia systemu, według prof. Meisnera brzmiały:

1. Otwór do wypływu zimnego powietrza w nagrzewanym pomieszczeniu powinien się znajdować $\mathrm{w}$ dolnych partiach pomieszczenia, ponieważ napływające ciepłe powietrze wprowadza się górnym wlotem i powietrze to będzie "wypychało" cięższe, zimniejsze powietrze.

2. Kanały odprowadzające zimne powietrze mogą wychodzić na zewnątrz budynku, ale bardziej ekonomiczne jest połączenie wszystkich kanałów z ciepłym powietrzem otwierających się $\mathrm{w}$ górnych partiach pomieszczenia i kanałów z zimnym powietrzem otwierających się w dolnych partiach pomieszczenia.

3. Kanały rozprowadzające ciepłe powietrze powinny być wykonane z materiału będącego złym przewodnikiem ciepła.

W artykule omówione zostały różne warianty ogrzewania ciepłym powietrzem w zależności od typu wnętrz, jakie miały być ogrzane: duże hale fabryczne, kilkupiętrowe budynki i małe mieszkania. Pomimo takiej różnorodności pomieszczeń zasada działania ogrzewania ciepłym powietrzem wszędzie była taka sama.

Meisner zaleca, aby piec był szczelny i zbudowany z dobrych materiałów, co zapobiegnie przedostawaniu się do pomieszczeń dymu oraz

5 W. Szubert, Ze studiów nad czasopiśmiennictwem Królestwa Kongresowego „Izys Polska”, „Zeszyty Naukowe Uniwersytetu Łódzkiego” 1958, seria I, z. 8, s. 167-204. 
zniweluje niebezpieczeństwo pożaru. Konieczne jest również uszczelnienie okien i drzwi przeciw napływowi powietrza zewnętrznego, aby tylko kontrolowaną przez nas ilość powietrza wprowadzać do wnętrza. Otwory przy kanałach należy zabezpieczyć kratkami żelaznymi przede wszystkim przed gryzoniami. Autor poleca piec „zwyczajnej wielkości”, który mocniej opalany powinien wystarczyć do ogrzania 6-8 izb 6 . W domach mieszkalnych kanały powinny mieć przekrój kwadratowy ( 8 x 8 cali), natomiast w fabrykach kanały powinny być większe: od 15 do 18 cali $^{7}$.

W 1823 roku w „Izys Polska” pojawia się kolejny artykuł o ogrzewaniu i wietrzeniu mieszkań za pomocą ogrzanego powietrza. Tym razem jest to wyjątek $z$ rozprawy $P$. Sylwestra, $z$ opisem i rysunkiem pieca wspomnianego już P. Perkins'a. Autor artykułu jako alternatywę dla kominków powodujących nieprzyjemne ciągi powietrza proponuje ogrzewanie, w którym następuje połączenie wydzielania ciepła do pomieszczenia z przepływem świeżego powietrza, które w zimie musi być podgrzane a latem schłodzone. Według autora do pomieszczenia należy wpuścić tylko tyle świeżego powietrza, ile potrzebują ludzie przebywający w tym pomieszczeniu oraz tyle, ile potrzeba do spalenia materiału opałowego. W pomieszczeniu powinny znajdować się dwa źródła powietrza zewnętrznego: otwór wpuszczający powietrze do pokoju w takim miejscu, aby ciąg nie czynił przykrości ludziom oraz otwór, przez który powietrze opuści pomieszczenie, występujący zazwyczaj w kominie - co dla dużych pomieszczeń, jak sugeruje autor artykułu, może być niewystarczające.

W „Dzienniku Wileńskim” z 1830 roku znajdziemy zestawienie dostępnych na rynku sposobów ogrzewania w zależności od realnej wydajności ciepła.

1. Piece zwyczajne, „źle urządzone” wydają 0,01 lub w najlepszym razie 0,08 części ciepła.

2. Piece Rumforda wydają od 13 do $14 \%$ ciepła $^{8}$.

6 P. Meisner, O ogrzewaniu mieszkań, fabryk, suszarń, s. 308-330.

7 Cal angielski - jednostka długości, $1 \mathrm{cal}=25,40 \mathrm{~mm}$.

8 Hrabia Rumford (sir Benjamin Thompson), z pochodzenia Amerykanin, zaprojektował w 1795 roku piec, w którym udoskonalił konstrukcję kominów, tak 
3. Piece lepszego urządzenia wydają od 20 do $35 \%$ ciepła.

4. Tak zwane ciepłotwory (caloriferes) wydają ciepła do 50\%.

Mówiąc o piecach lepszego urządzenia, autor prawdopodobnie miał na myśli kominki Galtona. Według Zajączkowskiego (1878) wydajność grzewcza takiego kominka wynosiła maksymalnie $35 \%{ }^{9}$. Autor chwali nowy typ ogrzewania nie tylko ze względu na czynnik ekonomiczny, ale i ze zwględu na wygodę związaną z opalaniem tylko jednego pieca, podczas gdy w całym budynku jest ciepło dzięki systemowi rur rozprowadzających to ciepło.

Informacje na temat kaloryferów znajdujemy w publikacji Szpadkowskiego z 1885 roku. Autor opisuje system grzewczy zainstalowany w Archiwum Hipotecznym przy ul. Miodowej w Warszawie w roku 1841. Jest to ogrzewanie powietrzne, którego działanie Szpadkowski opisuje w następujący sposób: „Kaloryfer, jest to w małej suterenowej izbie, szczelnie murowanej, kocioł żelazny, napełniony wodą pod którym tli się ogień przez całą zimę i wodę zagrzewa. Od ciepła wody ogrzewa się powietrze świeże, ze dworu rurami do izby owej ściągane. To właśnie powietrze kanałami w murach osadzonemi, z jednej izby rozchodzi się po wszystkich piętrach do wszystkich pokoi. W pokojach mała, zręczna rozetka, przy wylocie kanału umieszczona, dowolnie otwierana, wpuszcza w czasie żądanym wymaganą ilość ciepłego powietrza"10. Jak podaje autor artykułu, powietrze dopływające do pomieszczeń rozgrzewało, osuszało się i nabierało nadmiernej rozprężliwości, co z kolei utrudniało oddychanie. Próby dowilżania wnętrz za pomocą naczyń z wodą powodowały, że „książki hipoteczne wilgnąć zaczęły”. Pomimo tych niedogodności było to urządzenie na owe czasy bardzo nowoczesne.

by mniej dymiły: zwężenie wylotu komina, zmniejszenie powierzchni paleniska, pochylenie bocznych ścianek - zwiększało to powierzchnię nagrzewającą pomieszczenia. Kominki rumfordowskie były bardzo popularne w tym okresie w Anglii (W. Rybczyński, Dom: krótka historia idei).

9 M. Zajączkowski, Przewietrzanie mieszkań i ich ogrzewanie ciepłem powietrzem, „Przegląd Techniczny” 1878, t. VII, s. 193-204.

10 T. Szpadkowski, Piece ogólne (kaloryfery), „Inżynieria i Budownictwo” 1885, t. VII, s. 231-232. 
Artykuł M. Zajączkowskiego z 1878 roku zamieszczony w „Przeglądzie Technicznym” jest pewnego rodzaju podsumowaniem ogrzewania ciepłym powietrzem i prawidłowego przewietrzania. $\mathrm{W}$ artykule zestawione zostały znane systemy grzewcze, podano ich zalety i wady. Główną zaletą ogrzewania płaszczowego prof. Meisnera jest ogrzewanie powietrza $\mathrm{w}$ pomieszczeniu zarówno w kierunku poziomym, jak i pionowym. Jeżeli doda się do tego sprawnie działającą wentylację, to „nie wywołuje oziębienia i przeciągów, ponieważ wprowadzone powietrze zewnętrze rozgrzewa się wprzód nim dochodzi do mieszkania. Zepsute powietrze, będące zarazem chłodniejszem zajmuje dolne warstwy i kanałem uchodzi całkowicie do komina. Ponieważ wymiana powietrza następuje od powały ku podłodze, łatwiej jest skontrolować organem powonienia o ile takowa nastąpiła"11. Na podobnej zasadzie, czyli wykorzystującej naturalną różnicę temperatur, działał system wentylacyjny prof. Sicardsburga.

Zajączkowski wymienia również wady systemu grzewczego prof. Meisnera. Główną wadą jest, mimo działającej wentylacji, zbytnie wysuszanie powietrza. Ogrzewanie to ponadto może powodować ból i zawroty głowy, nudności, rozdrażnienie. Jak wielkie znaczenie miały te niedogodności dla ówczesnych ludzi, którzy zaczęli przykładać do spraw zdrowotnych dużą wagę, niech świadczy fragment artykułu z 1889 roku zamieszczony w czasopiśmie "Zdrowie. Miesięcznik poświęcony hygienie publicznej i prywatnej”:

„Zachodzi więc pytanie w jaki sposób należy urządzić odnowę powietrza w mieszkaniach, aby odpowiadały najlepszym warunkom sanitarnym? Codzienne doświadczenie uczy nas że człowiek ciepło ubrany może znosić powietrze bardzo chłodne i suche jeżeli nie jest narażony na mocne prądy powietrza. Inaczej się rzecz ma gdy prądy te da się odczuć; wtedy bowiem nie wszystkie części ciała oddają w równej mierze ciepło, następuje upadek równowagi w parowaniu powierzchni i oziębienie organów wewnętrznych. Najlepsza byłaby wentylacja przez mury porowate, gdyby w rzeczywistości materjały znane mogły odpowiadać

11 M. Zajączkowski, Przewietrzanie mieszkań i ich ogrzewanie ciepłem powietrzem, s. 204. 
tym warunkom. Właściwie mówiąc ciągłe i doskonałe przewietrzanie mieszkań w obecnym stanie wiedzy nie da się uskutecznić.

Stosunkowo bardzo dobrą można byłoby otrzymać wentylację za pomocą otworów umieszczonych w dwóch ścianach przeciwległych zawsze otwartych i tylko częściowo lub całkowicie zakrytych w razie burzy lub większej niepogody. Otwory te zmieniać można byłoby przez szyby dziurkowate; oprócz tego do odnowy powietrza należałoby zachować wentyle umieszczone w górze.

Przewietrzanie mieszkań nie może być zadawalniającem, jeżeli nie zwróci się uwagi na materjały, z których budują się ściany. Wszystko co nas otacza mury lub odzież - wszystko to powinno być o ile możności najwięcej przenikliwem. Wentylacja murów zamienia zamknięte mieszkania na przyrządy dezynfekcyjne, wszelkie zaś urządzenia bez zastosowania materiałów przenikliwych dla gazów, dostarczą ilość powietrza nieznaczną w porównaniu z tem, czego ustrój wymaga dla prawidłowej odnowy gazów w płucach"12.

$\mathrm{Z}$ przedstawionego materiału widać, że w XIX wieku rosło zainteresowanie zagadnieniami związanymi z poprawą komfortu życia, przede wszystkim efektywnym ogrzewaniem wnętrz. Nowością było ogrzewanie pomieszczeń ciepłym powietrzem szczegółowo omawiane przez polskie czasopiśmiennictwo XIX wieku i dostępne dla zainteresowanego nowinkami technicznymi czytelnika.

12 Ogrzewanie i przewietrzanie mieszkań, „Zdrowie. Miesięcznik poświęcony hygienie publicznej i prywatnej” 1889, s. 780-781. 
Według Pettenkooffera należy wprowadzić 200 razy tyle powietrza świeżeg.0, ile człowiek w godzinie wydycha t. j. $200 \times 10$ st. sz. = $=2000$ st. $\mathrm{sz} .=60 \mathrm{~m}$. sz. Ilość te przyjęto we Francyi za podstawe przy obliczeniach i według Morin'a, potrzeba na godzinę:

dla zwykłego chorego . . . 60-70 m. sz.

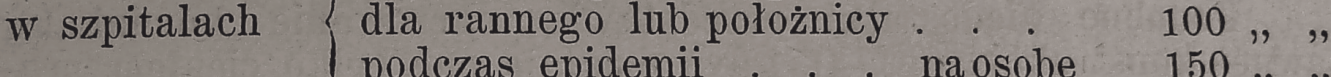

w więzieniach

w warsztatach $\{$ zwykłych mechanicznych

$\left\{\begin{array}{l}\text { chemicznych . . . . , } \\ \text { w dzień } \\ \text { w nocy }\end{array}\right.$

w koszarach $\left\{\begin{array}{l}\text { w dzien } \\ \text { w nocy }\end{array}\right.$

w teatrach . . . . . . . "

W salach podczas dłuższych zgromadzeń .

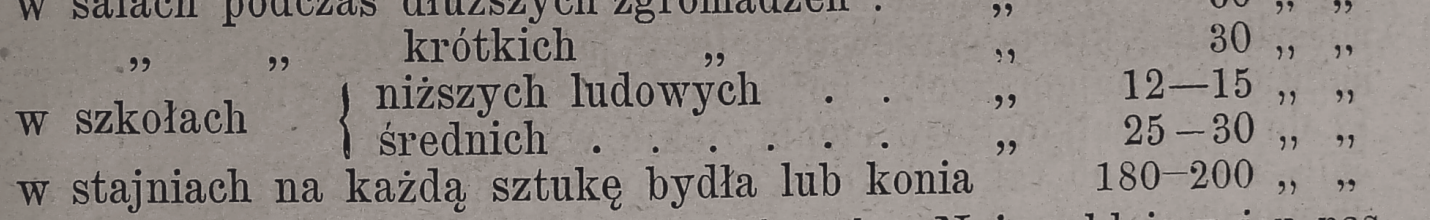

$50,,$,

$60,,$,

$100, "$

$30, "$, $40-50, "$, $40-50, "$, $60, "$,

Il. 1. Zapotrzebowanie na świeże powietrze $(\mathrm{m} 3 / \mathrm{h})$ w różnych wnętrzach według Zajączkowskiego („Przegląd Techniczny” 1878) 


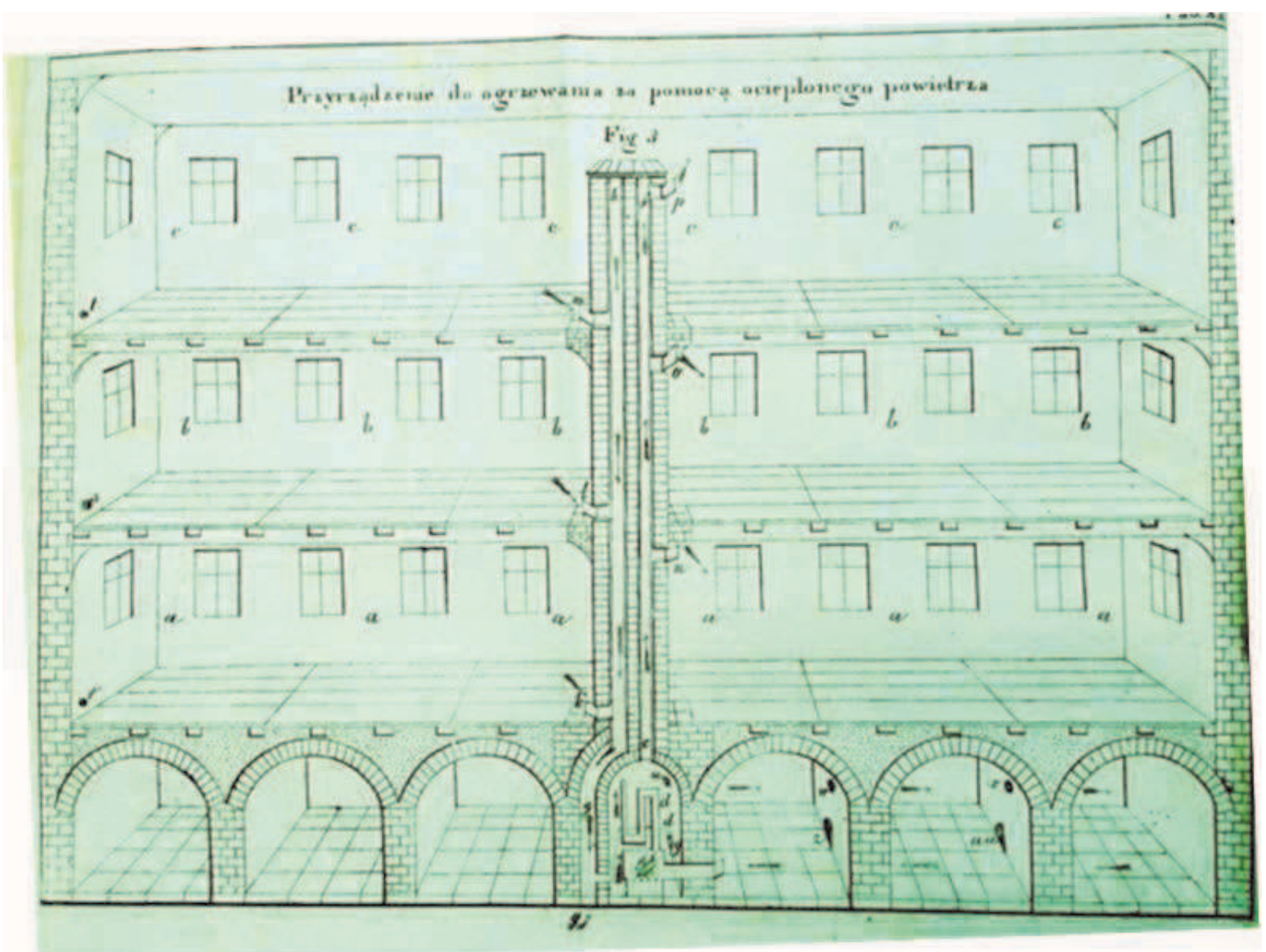

Il. 2. Schemat ogrzewania ciepłym powietrzem („Izys Polska” 1822) a, b, c - pomieszczenia ogrzewane ciepłym powietrzem $\mathrm{g} \mathrm{h}-$ kanał z zimnym powietrzem e f - kanał $z$ ciepłym powietrzem $\mathrm{k}, \mathrm{l}, \mathrm{m}$ - otwory $\mathrm{w}$ kanale $\mathrm{z}$ zimnym powietrzem wychodzące przy posadzce w pomieszczeniach $\mathrm{a}, \mathrm{b}, \mathrm{c}$

$\mathrm{n}, \mathrm{o}, \mathrm{p}$ - otwory $\mathrm{w}$ kanale $\mathrm{z}$ ciepłym powietrzem wychodzące przy sklepieniu w pomieszczeniach a, b, c

$\mathrm{q}$ (u spodu kanału g h) oraz $\mathrm{w}$ punktach $\mathrm{r}, \mathrm{s}, \mathrm{t}$ w pomieszczeniach znajdują się wpusty świeżego, zewnętrznego powietrza, wpusty zamykane są klapami i otwierane według konieczności 

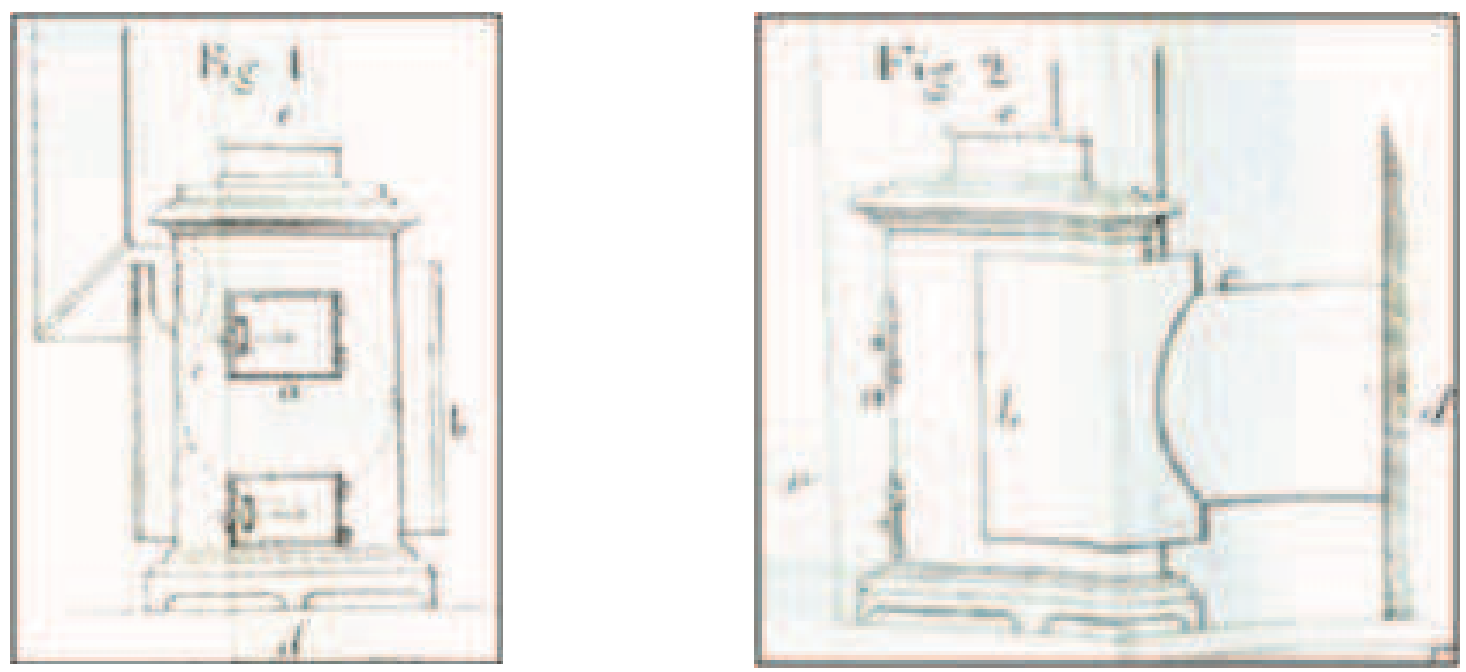

Il. 3a-b. Schemat pieca według Perkinsa („Izys Polska” 1823)

a - kadłub piecowy

b - żelazna blacha zespolona $\mathrm{z}$ kanałem powietrznym

c - kanał powietrzny mający średnicę prawie tak wielką jak piec

d - mur, w którym kanał powietrzny jest zasadzony

e - naczynie z wodą, które na bieżąco należy uzupełniać wodą

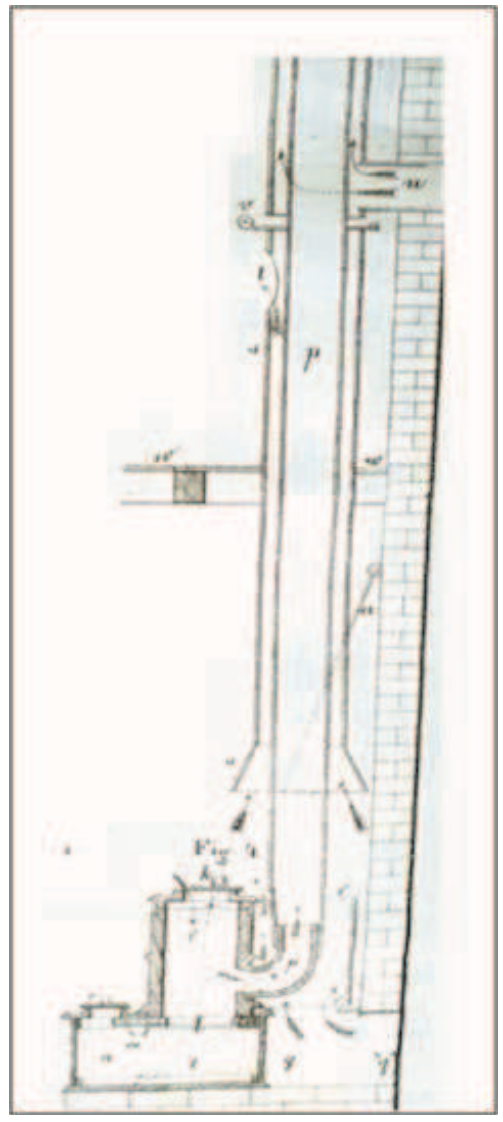

Il. 4. Przekrój poprawionego pieca Perkinsa („Izys Polska” 1823)

i - otwór do nakładania materiału opałowego do pieca

$\mathrm{n}$ - popielnik zamykany, prócz otworu o (kiedy rozpala się ogień, otwór ten należy otworzyć a przykrywę k zamknąć, kiedy ogień się już pali i rura ciągowa p jest gorąca, zamyka się otwór o a otwiera przykrywę k)

q - kanał powietrzny, który sprowadza świeże powietrze z zewnątrz przez ścianę, powietrze to przechodzi między piecem a żelazną osłoną $r$, pada na rurę $\mathrm{p}$ i się ogrzewa

$\mathrm{s}$ - pokrowiec otaczający rurę dymową, który świeże powietrze wciąga, rozgrzane prowadzi do wyższego piętra s i wypuszcza przez otwór $\mathrm{t}$ z - żelazna płyta, przez którą zagięta rura dymowa wchodzi w komin 


\section{Summary}

\section{Ventilation and heating systems described in polish 19th century journals}

The article covers issues concerning ventilation and warm air heating systems described in polish 19th century technical journals. The main emphasis of 19th century works was put on the improving the life comfort, especially heating. Technical news from Western Europe reached polish writers very fast. The article presents the way the ventilation and warm air heating systems worked in rooms of different types, as well as its advantages and disadvantages. 